\title{
Ibn Khaldun and Some Classic Views in 20th Century Linguistics
}

\author{
Abdullah Yaqub Samarah \\ Department of English Language and Literature, Faculty of Social Sciences, Umm Al-Qura University, Saudi Arabia \\ Email: aj.samarah@gmail.com
}

\begin{abstract}
The Muqaddimah of Ibn Khaldun or the Prolegomena (in Greek), is a book written by the Arab North African's Ibn Khaldun who records an early view of universal history. We need to point out that some modern thinkers view it as the first work dealing with the: philosophy of history, or the social sciences of sociology, demography, historiography or cultural history, and economics. We need to add that the Muqaddimah also deals with Islamic theology, political theory and the natural sciences of biology and chemistry. Ibn Khaldun wrote the work in 1377 as the preface or first book of his planned world history, the Kitab al-Ibar (lit. Book of Advice), but already in his lifetime it became regarded as an independent work. The following article will try to make a comparison between Ibn Khaldun's linguistic work in his Muqaddimah and some Western linguists i.e., Chomsky and Bloomfield. We have found that it is really mazing and interesting to show that there are some ideas, concepts, etc., discussed by Ibn Khaldun, appears again by some linguists who live in the 20th century.
\end{abstract}

Index Terms - classical linguistics, sociology and socioliguistics, syntax/grammar, Al-Muqaddimah/introduction, competence, performance, meaning, situation

\section{PURPOSE}

The purpose of my paper is to present an to make a comparison for some important work in linguistics by a person, who lived in 734 / 1333 AD to 780 / January of 1379 AD, before scientists like Chomsky, and Bloomfield..etc. This person came from Arabia (North Africa).

It should be pointed out that it is very difficult to the reader of Ibn Khaldun's book (The Introduction) to translate, or sometimes to understand what he meant exactly, because his language was somewhat cryptic, full of metaphors. Besides he wrote his book in five months in the year of 779 / 1358 AD.

I would like to point out to the section '7' I have discussed Ibn Khaldun's ideas and discussion about, 'language is form', and 'interconnection of language and history' but without any comparison between him and any Western linguist.

\section{INTRODUCTION}

It is an important contribution to the history of linguistics to show that some ideas and concepts reappear over and over again in the course of time. By presenting some of the central ideas of Ibn Khaldun and comparing them with the ideas of modern writers like, Chomsky and Bloomfield we may gain more truthful picture of the development of linguistic as a matter of science.

In the next section I will present the concepts which will be compared in this paper. I also find it necessary to give a presentation of Ibn Khaldun's work and ideas.

\section{BACKGROUND: SOME IMPORTANT THEMES IN 20TH CENTURY LINGUISTICS AND IN THE WRITINGS BY IBN KHALDUN}

\section{A. Competence}

Every science attempts to find some underlying regularities in order to formulate general knowledge.

In modern linguistics both Saussure and Chomsky have used the terms 'langue, and competence', respectively to refer to an abstract level of linguistic knowledge.

Interestingly enough, the Arabic writer Ibn Khaldun flourishing in the 14th century used the term Al MalakaH AllisanyaH to refer to a similar concept.

\section{B. Performance}

Both Saussure and Chomsky also postulated a purely observational level of language which they termed 'parole' and 'performance', respectively.

It seems that Ibn Khaldun in his use of the term Al Ada Alluqawi referred to a similar concept.

\section{Meaning and Situation}

Studies in pragmatics strongly suggest that the meanings of linguistic expressions are highly sensitive to the situations where they are used. 
Bloomfield, in his behaviouristic view of meaning strongly emphasised this.

Ibn Khaldun also observed this interdependence between meaning and situation.

In this paper I will compare the above three concepts as they have been expressed in writing by Ibn Khaldun, Chomsky, and Bloomfield.

\section{IBN H=ALDUN $=[$ IBN XHALDUN $]$}

Ibn Khaldun = $($ Ibn Xhaldun $) /(1333$ to 1379 AD) was one of the strongest personalities of Arabo-Muslim culture in the period of its decline. He is generally regarded as: a historian, sociologist, and philosopher. Thus his life has given rise to the most varied and even the most contradictory interpretations.

The Arabic book I have used here, is "Ibn Khaldu\#n's Introduction" republished in 1984. From reading this book I have become aware of similarities between Ibn Khaldun's ideas and Western ideas by the aforementioned writers.

Dr. Zakaria, M (1986), I have found it very useful to present here, and it was the main book I have used to deal with my topic. This book has discussed and demonstrated the main cases which Ibn Khaldun has talked about on one hand, and comparing these theories with the modern theories according to the Western linguists like, Chomsky, Bloomfield, etc on the other hand.

Zakaria (1986), also has chosen specific subjects from Ibn Khaldun's book, these subjects are concerned mostly with "Competence, Language, and the Grammar of competence", etc. Nevertheless, Ibn Khaldun's book dealt very much with sociology. Besides that Ibn Khaldun's book includes many other subjects which dealt with linguistic problems, dialects, solidarity, abbreviation, theology, etc.

Note, in addition to the book I have mentioned above I have also studied the original text too.

\section{A. His Life.}

Ibn Khaldun was born in Tunisia, in Ramadan of May 734 / 1333. From an 'Arab family' which came originally from the H3ad3ramawt $=($ South Yemen before $)$. He had a great grandfather, Abu\# Bakr Ibn Al-H3asan who wrote a treatise on Adab al-Katib= (literature of writer), (Lewis et al, 1971, p. 825).

Ibn Khaldun's life was divided into three parts:

1. The period up to 20 years was occupied by his childhood and education.

2. At the age of 23 , continuing his studies, his started taking an interest in politics.

3. At the age of 31 he was established as a scholar, teacher and magistrate.

The first two periods were spent in the Muslim West and the third was divided between the Mag\#rib = $($ Morocco $)$, and Egypt.

\section{B. His Work}

Ibn Khaldun was known primarily for his writing on morals in:

Al-C=ibar $\quad[$ al $\div$ ibar $]=($ The Morals $)$

and his writing on language and sociology in:

Al-MuqaddimaH $=($ Introduction $)$

But he wrote other works which have not all survived.

\section{1. $\mathrm{Al}-\mathrm{C}=\mathrm{ibar}=($ The Morals $)$}

This book contains an intelligent arrangement of facts and detail and the scope of the account, remains, in the opinion of the specialist who has made most use of it, an incomparable tool, particularly "for the two centuries nearest to our author, the 13th and the 14th". It should also be added that this work, often disappointing on the history of the East, is generally valuable especially for the Muslim West, and in particular for the Berbers. I have found it interesting to give an overview of this book, because it considers as the second main book to Ibn Khaldun, but the main book which I am going to deal with in the present paper is 'The Introduction' which will be discuss below.

2. Al-MuqaddimaH = (The Introduction)

His main work has universal value; In the author's intention, and as the title indicates, it is an introduction to the historian's craft. It is presented as an encyclopaedic synthesis of the methodological and cultural knowledge necessary to enable the historian to produce a truly scientific work.

His Exposition in Al-MuqaddimaH = (The Introduction).

Ibn Khaldun divided his introduction into six long chapters which in their turn are subdivided into many paragraphs of varying lengths and often mathematically arranged.

Chapter (1). A general treatise on human society. He made an outline of this study of the influence of environment on human nature, an ethnological and an anthropological study.

Chapter (2). On the societies of rulers, and generally speaking, fairly primitive civilisation.

Chapter (3). On the different forms of government, on states and situations.

Chapter (4). On the societies of urban civilisation. That is of the most developed and sophisticated forms of civilisation.

Chapter (5). On industries and economic affairs in general.

Chapter (6). On scholarship, literature and cultural matters (Lewis et al, 1971, p. 829) not inflectional rules by itself'. 
Thus the atypical figure of Ibn Khaldun in Arabo-Muslim culture has been unanimously considered since his discovery in Europe, as that of an authentic genius, "un penseure genial et aberrant" whose MuqaddimaH represents 'one of the solemn moments of human thought'. (Lewis et al, 1971, p. 830)

Ibn Khaldun's life has been judged variously, and in general rather severely. There is certainly no doubt that he behaved in a detached, self-interested, haughty, ambitious, and equivocal manner. He does not attempt to hide this and openly describes in his Tac=rif $=$ (definition), his successive changes of allegiance. He has been accused of fickleness and a lack of patriotism. Ibn Khaldun was an astonishingly clear thinker as he proves in his MuqaddimaH = (Introduction). It is true that his behaviour was dictated by ambition, the desire of power, a taste for adventure, and even a complete ruthlessness in political matters; but it is unlikely that this was all. It would be strange if the theoretician of $\mathrm{C}=\mathrm{as} 3 \mathrm{abiiaH}=($ Purism $)$ did not envisage a plan, perhaps rather vague, for the restoration of Arabo-Muslim civilisation which he clearly saw to be in its death-throes. (Lewis et al, 1971, p. 828).

\section{COMPARISON AND THEORETICAL DISCUSSION}

First of all I would like to mention the problems which have been discussed from some of Western linguists during the present century, then I will introduce Ibn Khaldun's ideas after each one of these problems.

These linguists are as follows: Chomsky, and Bloomfield.

\section{A. Chomsky, and Ibn Khaldun; "Competence \& Performance"}

\section{Chomsky}

Chomsky is best known for his syntactic description of language (presented in 1965 in Aspects of the theory of syntax).

Chomsky (1965) uses his term competence to denote an individual's knowledge of language.

One of the most striking features of 'competence' is Chomsk's idea of underlying deep structures in syntax. This idea seems to be coherent with the abstractness of competence: competence is not directly open to inspection.

It is not quite clear how Chomsky thinks competence is reflected in performance. What he has pointed out is that mistakes in performance occur very often because of psychological reasons like, division of attention, and nervousness. So Chomsky disregards much data and every kind of grammar mistake.

It should be pointed out that such data occurs frequently in ordinary spoken language.

I have found it necessary to mention Chomsky's definitions of 'competence, and performance' and their connection with the terms, 'speaker, listener, and acceptability' according to Chomsky:

A) Competence is the knowledge of users of a language about the language.

B) Performance according to Chomsky. is the use of the language in practice or, in concrete situations.

C) I could say here that the performance is the direct reflection of competence. But this is not the case for there are so many false starts, deviation from rules, etc in natural speech situation.

D) On the other hand, according to Chomsky; All of the communications are effecter!..because both: speaker \& listener have competence of a language and are involved in performance.

E) The term of Acceptability refers to utterances that are perfectly natural and immediately comprehensible without paper and pencil analysis and in no way bizarre or outlandish. Acceptability is a concept that belongs to the study of performance and grammaticalness / grammaticality belongs to the study of performance.

2. Ibn h=aldun [Ibn XHaldun]

Ibn Xhaldun's idea here which had come before Chomsky is; AlmalakaH llisaniaH means 'tongue's management', roughly, = 'competence', which is to have competence generally, and differs from how to show this competence in communication. The term of ' how to show this competence' is; Al Ada) Allug=awi\# means 'linguistic performance' = 'performance'. Then competence is guiding performance. (Ibn Khaldun, 1984, p. 1083, 1081)

Ibn Khaldun added, 'the knowledge of inflectional rules like we find in syntax or in language rule is not an inflectional rules by itself'. (Ibn Khaldun, 1984, p. 1082)

Then competence is the ability to use language in the right way= 'the right and correct way', in different situations for speaking or writing, and it is not necessary to fulfil the inflection rules precisely. (Ibn Khaldun, 1984, p. 1082)

This shows that Ibn Khaldun had some general ideas about the importance of pragmatics.

1) Ibn Khaldun's definition of competence.

"Competence is characters, and colours which do not crowd at once or at the moment. And the best type of it which occurs by nature". (Ibn Khaldun, 1984, p. 721).

He meant, that the competence does not come immediately, but gradually in the acquisition of language, besides his idea was that language should be learned in natural situations.

Observe, Ibn Khaldun warned against the mixing of languages both for, religious reasons and for protecting competence.

Ibn Khaldun gave also special definitions of competence:

a) competence is the knowledge of communication and expression

b) competence (lexicon quantity) can differ from one society to another.

c) competence consists of sounds which connected with meaning. 
d) competence is tongue action.

e) competence is convention.

From the above five definitions according to Ibn Khadun we can consider the advance, or the value of these definitions in modern linguistics.

2) Competence conditions

According to Ibn Khaldun, competence needs certain conditions to develop. Two very general conditions are:

(1). a good teacher,

(2). a good dialect area.

I think it is important to point out that, Ibn Khaldun is much more concrete in his discussion of competence than Chomsky. Chomsky's concept of 'innate ideas' is much abstract than Ibn Khaldun's. Since Ibn Khaldun thinks that a good teacher, e.g. can serve as a model for competence, then it is quite clear that performance and competence are two sides of the same coin: the good teachers performance is a model of competence for learning students. In the same way we could also understand Ibn Khaldun's ideas about 'good dialect area'.

Then Ibn Khaldun goes on to mention some more special conditions, I will try to translate them as much as I can:

AlmalakaH mustah4kamaH,

A). language must have much poetry.

AlmalakaH g\&ayyidaH,

B). the individual must keep by heart the good quality of linguistic details.

AlmalakaH rasih=aH,

C). resistance against bad influence of language.

AlmalakaH tammaH,

D). increasing the conscious knowledge of language.

AlmalakaH mustaqirraH,

E). concentration on the form of the language.

Referring to the previous conditions of competence, Ibn Khaldun had explained an important factor without which the competence would not occur. That is:' the competence depends on the one and only language, which is the mother tongue or the society language, which is grown up with the person since his/her birth. And it does not relate or connect only by sex = (nationality in Arabic expression), or to a special nation (Ibn Khaldun, 1984, p. 1053). Clearly, Ibn Khaldun was language purist.

Ibn Khaldun at the same page above, he discussed and meant the person who grown up in a society who speak only one language as native, and he did not discuss the society who speak two languages (bilingual), or more as native.

Also Ibn Khaldun added here, 'if the foreign tongue preceded the mother tongue for certain person in certain society, since childhood this decrease the level of competence in his or her mother tongue'. (Ibn Khaldun, 1984, p. 1053)

Inb Khaldun's definition of competence consisted of six main statements:

(1). competence or (language) is the knowledge of communication and expression.

(2). competence or (language) form's which is vary from one society to another.

(3). competence or (language) consists of sounds which contains on meaning or (semantic).

(4). competence or (language) is tongue action.

(5). competence or (language) is convention.

(6). speaking (as the result of competence) is the main process.

Ibn Khaldun as we have seen above, has mentioned six definitions which are related to competence, and language descriptions, which have been discussed in linguistics during the modern time.

3) Destroying competence

According to Ibn Khaldun, there are certain threats against linguistic competence;

a) spoilt competence, Ibn Khaldun had explained how the competence may be spoilt, if a speaker is exposed to another language. And he had given an example about how the Arabic tongue spoilt gradually after communicating with non-Arabic people, then competence started becoming weaker, because of this foreigner tongue.(Ibn Khaldun, 1984, p.1056-1057)

b) the mix of competence, also according to Ibn Khaldun the speaker's competence of his real mother tongue will be reduced $=$ (competence according to Ibn Khaldun expression) because of some reasons:

(1). the interaction between the mother tongue and some other languages,

(2). this interaction will generate new competence, because of this mix which happened between two or more kinds of competence. e.g. the Arabo-Islamic domain conquered a big part of the world, and that time this interaction between the Arabic and the rest of the local languages took place (Ibn Khaldun, 1984, p. 1079)

c) competence change, Ibn Khaldun explained that this change could be observed morphologically in word inflection. However this competence (classic mother tongue according to Ibn Khaldun) was spoilt when Arabic spread to; As\&s\&am = (Syria, Jordan, Lebanon, \& Palestine $),$ Egypt, and North Africa $=($ Tones, Algeria, and Morocco $)$, then the speaker's competence of this tongue changed into that of another language. (Ibn Khaldun, 1984, p. 1074-1075)

Later, Ibn Khaldun observed that, 'to keep this competence $=$ (classic mother tongue) we can protect it from being mixed spoiling with other languages. 
Then he also gave a definition of competence: 'It is a particular character that we can deal with in order to feed it and to make it rich'.

Then Ibn Khaldun ended up with performance which he characterized, as much as good= (the good knowledge) that each person keep in his brain or by listening, to use this language and this will expand his competence (Ibn Khaldun, 1984, p.1112)

Ibn Khaldun wanted to concentrate on a very important point here, this point deals with high or the highest level of language. And he recommended us to concentrate our efforts to keep and to deal always with the highest level of language $=($ that is the language of Qur-an). And as much as each person keeps of language as much as he or/she serves his or/her language in the best way, then their competence becomes stronger. Also Ibn Khaldun has hinted to the variation of perception between persons and explained that it (perception) differs in degree between individuals, and this difference connected with what type of perception and competence affected on this person from outside.

3. The comparison between Ibn Khaldun and Chomsky

Competence and Performance

\section{A) Similarities}

The terms competence and performance

1). Chomsky (1965) uses the term competence to refer to the individual's knowledge of language. Chomsky also introduced the term performance for referring to observable behaviour on part of the language user.

Ibn Khaldun used the term Al MalakaH AllisanyyaH = 'competence' for referring to a similar concept as Chomsky has done. In a similar way like Chomsky, Ibn Khaldun also talked about observable behaviour and then used the term Al Ada Alluqawi = 'performance'

Both writers seem to postulate an abstract level of linguistic knowledge and one more observable level of language.

So far there are striking similarities between the two writers, but I will argue that there are also differences.

\section{B) The Differences}

\section{1). Innate ideas}

Chomsky's competence exists inside every human being and his innate idea much abstract than Ibn Khaldun.

Ibn Khaldun 'Innate idea' he thinks that e.g. a good teacher can serve as a model for competence, so he thinks you acquire language just by learn it.

2). Competence and language acquisition

Chomsky. Learning language is not necessary by natural situation.

Ibn Khaldun. Language should be learned in natural situation.

3). Conditions of competence

Chomsky. Competence do not require any condition.

Ibn Khaldun. To develop competence needs certain conditions: a good teacher, and a good dialect area.

Ibn Khaldun mentioned five conditions related to competence. Besides that he explained important factor too: 'the competence depends on the one and only language which is the mother tongue or the society language, which is grown up with the person since his/her birth. And it does not relate or connect only by sex = (nationality in Arabic expression), or to a special nation' (Ibn Khaldun, 1984, p. 1053).

4). Mixing language

Chomsky. Was not warred against the mixing of language.

Ibn Khaldun. Was warred against the mixing of languages for two reasons: religious reason (to keep Quran language), and to protect competence (the unmixed language).

5). Competence in general

Chomsky. Studied competence mostly.

Ibn Khaldun. Concentrated more on both competence and performance (for reasons have to do with 'language purism') and we see this in his 'Introduction' repeated several times.

The differs is that how to show this competence in communication. Ibn Khaldun hinted above to how to show to the individual style for the knowledge of language. Also his definitions of competence which are additional information corresponding to his definition above:

a) competence is the knowledge of communication and expression

b) competence (lexicon quantity) can differ from one society to another.

c) competence consists of sounds which connected with meaning.

d) competence is tongue action.

e) competence is convention.

6). Performance style

Chomsky.in performance. Disregards much data and every kind of grammar mistake.

Ibn Khaldun performance. Is to use language in the right and correct way, and in different situations for speaking or writing, and it is not necessary to fulfil the inflection rules precisely.

This shows Ibn Khaldun's idea about the importance of pragmatics.

7). Relation between performance and competence

Chomsky. Does not give account for the relation between performance and competence except for some remarks 
about performance errors.

Ibn Khaldun. Said that performance and competence are two sides of same coin: the good teachers performance is a model of competence for learning students, besides his idea about 'good dialect area'.

8). Focusing their studies

Chomsky. Concentrated more on the concept of competence.

Ibn Khaldun. Concentrated on both concepts competence and performance in parallel.

9). Language purism

Chomsky. Was not language purist.

Ibn Khaludn. Was really language purist. The above discussion showed us this character of him.

10). Performance mistakes

Chomsky argued that mistakes in performance occurs very often because of psychological reason/s like, division of attention, and nervousness, etc.

Ibn Khaldun.referred under the section (5.B, 3) 'destroying competence' that there are certain threats against linguistic competence which mentioned above are:

a) spoilt competence, Ibn Khaldun had explained how the competence may be spoilt, if a speaker is exposed to another language.

b) the mix of competence, also according to Ibn Khaldun the speaker's competence of his real mother tongue will be reduced because of some reasons:

(1). the interaction between the mother tongue and some other languages,

(2). this interaction will generate new competence, because of this mix which happened between two or more kinds of competence.

c) competence change, Ibn Khaldun explained that this change could be observed morphologically in word inflection.

11). The term 'acceptability'

Chomsky defined and discussed the term of 'acceptability' as a concept that belongs to the study of performance and grammaticalness / grammaticality belongs to the study of performance.

Ibn Khaludn his view was more to concentrate on performance, for reasons having to do with 'language purist'. Besides he did not discuss the term of acceptability in separate.

I think that Ibn Khaldun's discussion and definitions were wider and more precise than Chomsky's discussion in the aspects of 'competence and performance'. The above comparison showed us these differences clearly.

\section{B. Ibn Khaldun [Ibn XHaldun] and the Connection between Syntax and Semantics}

\section{Chomsky}

Chomsky has discussed this phenomenon and his view was, syntax and the structure of sentence says can be studied independently of meaning, and this is really strong claim.

Not all linguists, however, have supported Chomsky's claim. In formal semantics, for example, there is an assumption that syntax and semantics are dependent on each other.

2. Ibn $\mathrm{h}=$ aldun [Ibn XHaldun]

Ibn Khaldun classified "the Arabic tongue"= (Arabic language) into four parts or subjects: language, syntax, rhetoric, and literature. (It is a little mysterious to mention language and syntax as two different subjects . The explanation may be that he meant something more special by the term language) Then he explained, we can say here that syntax is very important, and by syntax we can recognize the main intention of semantics or (meaning), by intuitively observing syntactical relations like, subject and object, topic and comment, we will find out the meaning of the sentence. (Ibn Khaldun, 1984, p. 1059)

So, that means that they are not separated in Ibn Khaldun's theory of language.

Then Ibn Khaldun gave us examples from Arabic, and how when we change the subdivision movement positions (or anyone of them) this will change the whole meaning of the sentence, phrase, or even the word.

Another observation Ibn Khaldun made under 'rhetoric subject's'. He said, "For each occasion for the Arab, there was its own and suitable talk, this talk must be connected very much by this occasion, but this must occur after completing the inflection and its proper meaning". (Ibn Khaldun, 1984, p. 1064)

Also Ibn Khaldun referred to the corruption of the Arabic language, and explained, that this corruption was caused by insufficient knowledge of the Arabic rules (syntax). Then he gave an example, that is the same as the person who has only theoretical knowledge of some skill but no practical experience. (Ibn Khaldun, 1984, p.1081)

Ibn Khaldun said that language needs two things:

1). Enough rules.

2). Language user who follow the rules. (Ibn Khaldun, 1984, p. 1085)

3. The comparison between Ibn Khaldun and Chomsky

Syntax and Semantics

A) The Similarities

1). Syntax and structure

Chomsky discussed the phenomenon of syntax and the structure of sentence independently. 
Ibn Khaldun discussed the above phenomenon independently, and showed us through some Arabic examples how when we change the subdivision movement positions (or anyone of them) this will change the whole meaning of the sentence, phrase, or even the word.

2). Language rules (syntax)

Chomsky described the language rules (syntax) and showed the necessity of these rules in the language.

Ibn Khaldun discussed the importance of the language rules (syntax) and explained that language needs two things: enough rules, and user/s who follow these rules.

\section{B) The Differences}

1). Syntax and meaning

Chomsky distinguished between syntax and meaning.

Ibn Khaldun did not separate between syntax and semantics in his theory of language.

2). Language tongue

Chomsky did not classify the English tongue (English language)

Ibn Khaldun classified the Arabic tongue (Arabic language) into: language, syntax, rhetoric, and literature (the explanation may be that he meant something more special by the term language).

3). Syntax and semantics

Chomsky discussed the importance of syntax but not the main intention of semantics.

Ibn Khaldun showed the importance of syntax and add that, by syntax we can recognize the main intention of semantics, by intuitively observing syntactical relations like, subject and object, topic and comment, we will find out the meaning of the sentence.

4). Inflection and meaning

Chomsky did not discuss the connection between inflection and its meaning during e.g. specific occasion talk.

Ibn Khaldun under the 'rhetoric subject' said, "for each occasion for the Arab, there was its own and suitable talk, but this must occur after completing the inflection and its proper meaning".

5). Rules corruption

Chomsky did not discuss the corruption of the English rules and or the reasons behind them.

Ibn Khaldun discussed and exemplified the corruption of the Arabic language, and the reasons behind them which are according to Ibn Khaldun are: insufficient knowledge of Arabic rules (syntax).

I think that Ibn Khaldun did not fall in the same claim as Chomsky's did, when he (Chomsky) claim that syntax can be studied independently of meaning.

Also another point I would like to hint to, Ibn Khaldun's use the expression "occasion" shows that he understood that language is connected with the situation were it is used.

Ibn Khaldun as we see above has mentioned meaning, after syntactical analysis, and this may be a reflection of his idea that meaning rests on syntax.

\section{Bloomfield and Ibn Khaldun, "Meaning and Situation"}

This is the last point I would like to discuss, comparing between Bloomfield and Ibn Khaldun (our scientist in the present study).

1. Bloomfield

Bloomfield (1933) in his stimulus-response view of meaning in language argued that meaning depends heavily on the situation.

Bloomfield has said, that meaning is created by uttering a linguistic form, a speaker prompts his hearer to respond to a situation; this situation and the response to it is the linguistic meaning of that form. Then, and according to Bloomfield also, meaning depends on situation.

2. Ibn h=aldun [Ibn XHaldun]

On the other hand said, "The Arabs were putting things =(uttering expressions) which has meaning by general, then they have used for each particular situations its own particular forms, and this is what has made the variation and the distinction between convention =(to put, according to Arabic) and the use of it".

Ibn Khaldun, gave example; "They have put and used the = (the expression) 'white colour' conventionally and generally for everything which contains white colour. Then they have replaced this expression and this happened because they found that it is necessary to give specific expressions to specific words which depends on particular situation as we will see this in the examples below which Ibn Khaldun gave referring to this discussion, As\&hab = (AShab which is the horse who has the white colour as a property), and Amlah3 = (Amla which is the sheep who has the white colour as a property), then the use of the white colour (as an expression) for all of the previous examples has corrupted (solecism) its meaning, and have lacked Arabic by using this expression later". ( Ibn Khaldun, 1984, p.1059)

However, we have seen from the previous explanation and examples, which Ibn Khaldun used, that the Arab used and still the aforementioned forms depending on particular situations.

Later, Ibn Khaldun argued that "competence in language should have a private form for private meaning too, and the difference only depends on the situation" (Ibn Khaldun, 1984, p. 1064, and Zakaria, 1986, p. 12)

3. The comparison between Ibn Khaldun and Bloomfield

Meaning and Situation 


\section{A) The Similarities}

1). Meaning and situation

Bloomfield discussed the idea which says that, every meaning behind any expression depends on a certain situation.

Ibn Khaldun discussed the same idea and said that, the Arab have used for each particular situations its own particular forms, and this what has made the variation occurs between convention and the use of it.

2). Needs and situation

Bloomfield's theory about meaning and situation, still use until today and depends on the needs of certain situation.

Ibn Khaldun. The Arab used (in the past very much) and still (but not as before) his theory also depends on their needs of certain situation.

\section{B) The Differences}

1). The study of meaning and situation

Bloomfield discussed this phenomenon specifically.

Ibn Khaldun discussed and exemplified this phenomenon by general.

2). Theory of meaning

Bloomfield talked about the general theory of meaning.

Ibn Khaldun explained the historical change only.

3). What depends on situation?

Bloomfield. Only the meaning depends on situation.

Ibn Khaldun. Language is located in situations which requires:

particular forms to particular meaning. Ibn Khaldun also gave the examples.

4). How is the meaning create?

Bloomfield. Meaning is created by uttering the linguistic forms.

Ibn Khaldun. The Arab more putting things (uttering expressions) which has meaning by general.

5). The reason/s behind meaning and situation

Bloomfield said that there is not necessary to be certain reason/s behind occurring this phenomenon (meaning depends on situation).

Ibn Khaldun said that there must be certain reason/s behind occurring this phenomenon.

Here, we have seen that Ibn Khaldun anticipated Bloomfield's theory that, language is located in situations which requires:

particular forms $\rightarrow$ to particular meaning

And not only the meaning depends on situation according to Bloomfield.

\section{CONCLUSION}

In my view Ibn Khaldun discussed competence in more details than Chomsky which has done. Furthermore, Ibn Khaldun suggested how performance and competence are related to each other, something which Chomsky has never discussed.

I have observed that Ibn Khaldun in his introduction book (Ibn Khaldun, 1984, p.1064, and Zakaria, 1986, p.117) contradicted himself referring to what he has said, "that forms are more important than meaning", then he said, "that studying language depends not only on forms, but meaning is the most important", because the last words =(the main conclusion and result' refers to the meaning).

Ibn Khaldun was language purist but not Chomsky. The conditions of competence according to Ibn Khaldun Chomsky did not discuss it. Destroying the competence according to Chomsky is psychological reason/s, but three different reasons according to Ibn Khaldun are mentioned previously. Ibn Khaldun shown the important of pragmatics through his discussion about speaking and writing rules which according to Chomsky disregards much data and every kind of grammar mistake.

Chomsky's claim in studying syntax and the structure of sentence can be studied independently was faced contrastly from Ibn Khaldun's discussion who did not separate between both of them. Ibn Khaldun supported his discussion in examples from Arabic tongue (Arabic language), subdivision movement position, rhetoric subject, occasion's talk, and ended up to the reason/s for corruption the Arabic language. Ibn Khaldun related all the aforementioned elements to the role of syntax. The language according to Ibn Khaldun needs two things: enough rules, and language user/s who follow these rules. It is very clear that Chomsky's claim was a way of Ibn Khaldun's discussion.

Later, Corresponding to Bloomfield and Ibn Khaldun we noticed that Ibn Khaldun anticipated Bloomfield's theory that language is located in situation because of this it needs: a specific form for each specific meaning, but not the meaning depends on situation according to Bloomfield's theory.

"Western reasons for neglecting Arabic linguistics"

I have found it important to mention some of the reasons which have excluded Arabic linguistics from the general history of linguistics:

1. Western linguistics have ignored the Arabic language and its linguistic tradition, the evidence is, Ibn Khaldun's ideas in the present study.

2. They have also neglected the time period during the middle centuries in general, and we know that in precisely this 
period the Arabic activities has appeared and developed in the mediaeval time of Europé!!.

3. Because of prejudice linguists, have no real interest of the civilisations of the other cultures which have no relation with Western society or culture.

4. Arabic linguists are rather weak in modern theory of linguistics nowadays. They have concentrated mostly on classics and traditional studies.

I have noticed also, that Ibn Khaldun connected his studies with the concept of competence very much, and from many perspectives, historically, geographically, accentually, and socially, etc.

\section{IBN HKALDUN 'LANGUAGE IS FORM, AND "THE INTERCONNECTION OF LANGUAGE AND HistORY"}

Under this section I will demonstrate Ibn Khaldun's ideas about 'language is form', and 'the interconnection of language and history' briefly.

\section{A. "Language is Form"}

As I have talked in the purpose of this paper that I am going to show Ibn Khaldun's ideas and discussion in both sections 5.2, and 5.3 and without any comparison between him and the other Western linguist.

Ibn Khaldun also discussed this phenomenon by connecting it with language. Language according to Ibn Khaldun depends on forms, which means that to know the linguistic $=$ (syntactic and morphological) forms is the main thing in language, and Ibn Khaldun recognized the importance of forms which are more important that substance or meanings.

Ibn Khaldun said, "know! that making any type of speech depends on forms, not meaning. Meaning and forms always go together".

Here it is quite clear that Ibn Khaldun made a contradiction in his writings, if he says that forms are more important than meanings then form and meaning can not be equally important.

Then Ibn Khaldun exemplified, "the creator of speech deals with forms, and he is guided by his knowledge of high Arabic spoken language, to be understood in the future".(Ibn Khaldun, 1984, p. 1110)

Ibn Khaldun continued, "and what is running on our tongue (our communication of language), are forms, but meaning is hiding inside the forms. Moreover the meanings are still inside each person's mind and he could use it anytime he decides to. For a person it does not take efforts to create meaning. On the other hand, forms require more effort". Ibn Khaldun continued, " forms are pattern of meaning". (Ibn Khaldun, 1984, p.1111)

The same contradiction as above appears again when Ibn Khaldun considered competence as able for creating new forms, and not new meanings. In addition to his more formal analysis of meaning he also used psychological insights -"psychological interest"- in his semantic analysis. He said "Meaning is always hidden inside human intention" (Ibn Khaldun, 1984, p. 1080). This explanation maybe has made him a pioneer in the linguistic field.

Ibn Khaldun ended up "if this forms competence was well controlled, then it removes the ambiguity between forms and meanings. And this is the relation between meanings and forms". (Ibn Khaldun, 1984, p. 1052, 1053)

Ibn Khaldun pointed out the importance of the concept intention (Ibn Khaldun, 1984, p.1080), and continued, "if the speaker gives the precise expression corresponding to a definite intention then he will remove ambiguity. And this is the real relation between meaning and forms" (Ibn Khaldun, 1984, p.1053-1052).

Then Ibn Khaldun distinguished between, form and substance, and he claimed; that competence is knowing the articulation or pattern which is the meaning content.

It is difficult to know precisely what Ibn Khaldun meant by this.

My interpretation is that competence is knowing how to perform.

\section{B. The Interconnection of Language and History}

It seems to me that Ibn Khaldun looked at history from two perspectives, from outside and from inside:

1. External perspective, means to look at history as a set of facts (countries, and past centuries, and books we have received, e.g. morals, celebrations, national change, civilisations, buildings, and destruction)

His idea was that, since everything changes language must also change.

Ibn Khaldun pointed out that the historical changes can be traced in language.

2. Internal perspective, represents a more analytical perspective of history, in this perspective there is a motivation to explain why and how these changes took place.(Ibn Khaldun, 1984, P.2-3)

It is clear that Khaldun's distinction between external and internal is not identical to diachronic and synchronic. Perhaps this distinction is only represents a gradual difference in the awareness that language chance and world change are related to each other.

Finally, I would like to say that I have not covered all problems which Ibn Khaldun discussed in his book (The Introduction), but I have tried to translate his ideas and I have tried to analyse some of his ideas and views through the present study as possible. And I wish that this study is going to give to the reader an explicit idea about the role of them. I wish that this study will give the reader an explicit idea about the role of Ibn Khaldun in the history of linguistics

\section{A NOTE ABOUT ZAKARIA'S AND HIS INTERPRETATION OF IBN KHALDUN'S WRITINGS}

Michael Zakaria was born in Lebanon, He graduated from Paris university in linguistics, he has been a university 
researcher in Arabic linguistics, he is currently working as a teacher of linguistics in Lebanon university.

His publications include:

1. Linguistics (the modern science of language), Birot, 1980.

2. Arabic grammar, transformation and generation in linguistics, a) the theory of linguistics, Birot 1982, b) the simple sentence.

3. Linguistics (the modern of science language), supplementary reading.

4. The theory of language acquisition, Birot, 1984.

5. Essai une Etude Generative de L'Arabe: syntaxe' Beyrouth, 1984.

6. Zakaria has done researches in:

a) comparative analyse between: Arabic and French.

b) preposition study in English and comparing it in Arabic preposition.

c) participated in teachers association in two activities:

1. Arabic language activity

2. teaching Arabic language.

A weak point in Zakaria's book, is that he has adopted and transferred much linguistic information from Ibn Khaldun's original text as it is and without enough or sometimes any interpretation. This is very difficult to understand for highly educated persons who speak Arabic as a native language. I myself have faced this problem in dealing with the original text, because translation is not the most important in these cases but to get to the writer's point of view is the most important, besides the translation from one language to another does not give always the exact meaning.

\section{ACKNOWLEDGEMENT}

I thank all persons who participated in the present conversations. My special thanks to the department of English language at Umm Al-Qura University at the Kingdom of Saudi Arabia who has supported me in order to formulate my paper in to the best.

As well as my grateful thanks to my colleagues at the English department who encourage me to submit my article to enrich and extend the academic researches under the command and the umbrella of Umm Al-Qura University.

Thanks to the professor Jan Retsö at the Arabic department in Gothenburg university for his help in getting the exact materials which have helped me in my present paper.

My special thanks to my teacher and adviser Sören Sjöström at the Linguistics department in Gothenburg university who assisted me very much to focus on the main ideas of my paper in order to present to the best way.

\section{REFERENCES}

[1] Bloomfield. L, (1933). "Language" Great Britain, London. Final published in the MIT Encyclopedia of Cognitive Science, ed. by Robert A. Wilson and Frank C. Keil, MIT Press, 1988, pp.90-91.

[2] Chomsky. N, (1965). "Aspects of the Theory of Syntax" Cambridge, Mass.: MIT Press.

[3] Alatas. S.F, (2006). "Ibn Khaldun and Contemporary Sociology”, International Sociology, Vol.21 No. 6, pp.782-95.

[4] Ibn Khaldun, (1984). "The Introduction". Fifth edition by Dar Alqalam, Beirut, Lebanon.

[5] Lewis. B. Menage, V.L. Pellat, ch. and Schacht, J. '3'. H-IRAM (1971). "Encyclopaedia of Islam". Published by Brill in four volumes plus supplement from 1913 to 1938. New Edition. Printed in Netherlands.

[6] Saussure. D. (1916). "Course de Linguistique Générale”. (5th edn, Paris, Payot, 1955). English translation by Wade Baskin, Course in General Linguistics (New York, Philosophical Library, 1959).

[7] Zakaria. M, (1986). "almlkah allsaniah fi mkdmah a'bn khldoun" 1st edition by The University Est for Studies and Publishing. Birout, Lebanon.

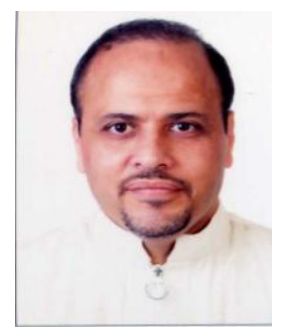

Abdullah Yaqub Samarah, Swedish nationality and Palestinian by origin, he was born on the 1st of March/1967 in Jeddah/Saudi Arabia where he received his basic and university studies. In 1988 he got his BA from the KAUV, in 1992 he moved to Gothenburg/Sweden to continue his higher education where he completed both: his MA in 1995 and M.Phil degrees in 2002, as well as his doctoral courses, major of 'General/Theoretical Linguistics', subject of 'Spoken Language Communication'. In 2004 he decided to move his dissertation to Exeter University/United Kingdom to work on his PhD. In 2006 he completed his Defense/Viva Vocia successfully. On the 6th of May/2008 he received his PhD officially in 'Linguistic Communication and Discourse Analysis'.

Dr. Samarah, and between 2004 and 2011, taught as Instructor and Assistant Professor in English, Linguistics, and Research Methodology in the Kingdom of Saudi Arabia. He is working now as Assistant Professor at U'ml-Qura University, Makkah/Saudi Arabia in the English Language Department.

In 2011 Dr. Samarah has published two articles through the IJAR Journal, are: 1. http://www.ijar.lit.az/literature.php?go=jll-august2010 "VIEWS OF APOLOGY IN LINGUISTICS: EXAMPLES OF ARABIC CULTURE” 2. http://www.ijar.lit.az/en.php?go=march2011 “ARABIC LINGUISTICS AND SIBAWAIHI” 